\title{
Physiological Activities of Hot Water Extracts from Ecklonia cava Kjellman
}

\author{
Eun Kyung Cho and Young Ju Choi *
}

\section{Department of Bio Food Materials, 1Department of Food and Nutrition, Silla University, Busan, 617-736, Korea}

Received August 26, 2010 /Accepted October 5, 2010

\begin{abstract}
The biological activity of hot water extract from Ecklonia cava Kjellman (ECE) was investigated to assess antioxidative, anti-skin aging, and nitrite scavenging abilities, as well as alcohol metabolizing activities. Antioxidant activity of ECE was measured by using 2,2-diphenyl-1-picryl-hydrazyl (DPPH) radical scavenging activity and superoxide dismutase (SOD)-like activity. DPPH radical scavenging activity and SOD-like activity of ECE increased in a remarkably dose-dependent manner, and were about $91.4 \%$ and $75 \%$ at $1 \mathrm{mg} / \mathrm{ml}$, respectively. The xanthine oxidase inhibitory activity was indicated to be about $70 \%$ at $1 \mathrm{mg} / \mathrm{ml}$ of ECE. Nitrite scavenging ability of ECE showed to be $93.6 \%$ at 1 $\mathrm{mg} / \mathrm{ml}$ and $\mathrm{pH} 1.2$. The influence of ECE on alcohol metabolism was demonstrated through the generating activity of reduced-nicotinamide adenine dinucleotide (NADH) by alcohol dehydrogenase (ADH) and acetaldehyde dehydrogenase (ALDH). The facilitating rate of ADH and ALDH activity by ECE was $167.2 \%$ and $334 \%$ at $10 \mathrm{mg} / \mathrm{ml}$, respectively. In addition, tyrosinase and elastase inhibitory activities of ECE were $58 \%$ and $72 \%$ at $10 \mathrm{mg} / \mathrm{ml}$, respectively. These results indicated that ECE has valuable biological attributes owing to its antioxidant, nitrite scavenging, alcohol metabolizing, and elastase and tyrosinase inhibitory activities.
\end{abstract}

Key words : Hot water extract, Ecklonia cava, elastase inhibitory activity, nitrite scavening activity, alcohol metabolizing activity

\section{서 론}

최근 급격한 생활환경의 변화와 식생활의 서구화로의 변모 로 뇌혈관질환, 심장병, 고지혈증, 고혈압 및 당뇨병 등의 순환 계 질환과 암으로 인한 사망률이 증가되고 있다. 이에 성인병 과 암, 노화 등을 안정성이 입증된 식물성 식품으로 예방하기 위해 식물체 추출성분에 대한 식품 관련 산업과 의약분야에서 실용화가 이루어져 왔으며, 연구대상이 되어 왔다. 하지만, 이 러한 연구는 대부분 육상 식물을 대상으로 이루어져 왔는데, 그 연구대상이 한계치에 이르고 있으므로 새로운 자원개발을 위해 해조류에 대한 관심이 증대되고 있는 실정이다[11]. 더욱 이, 최근 해조류의 다양한 생리·화학적 효과가 검증되면서 해조류에 관한 연구가 활발히 진행 중이다[18,19]. 해조류에는 각종 미네랄과 비타민 및 섬유소, 단백질이 풍부하게 함유되 어 있는데 특히, 알긴산, 퓨칸설페이트, 라미나란등 수용성 다 당류가 풍부하다. 이들은 많이 섭취하여도 독성이 없으며 퓨 칸설페이트와 알긴산 유도체들은 항당뇨, 항응고, 항염증, 항 종양 등의 효과가 있다고 알려져 있다[7,25]. 지금까지, 해조류 는 전 세계적으로 약 8,000 여 종이 알려져 있는데 그중에서 식용해조류는 50 여종에 불과하다. 이들은 전통약제, 식재료, 건강보조식품으로 사용되어 왔지만, 수 많은 비식용해조류에 대한 상업적 이용가치는 잘 알려져 있지 않다.

\footnotetext{
${ }^{*}$ Corresponding author

Tel : +82-51-999-5459, Fax : +82-51-999-6959

E-mail : yjchoi@silla.ac.kr
}

본 실험에 사용한 감태(Ecklonia cava Kjellman)는 비식용 해 조류로 갈조 식물 다시마목(Laminariales) 미역과의 식물로서 우리나라에서는 주로 제주연안 수심 $10 \mathrm{~m}$ 내외에서 서식하고 있다. 길이는 $1-2 \mathrm{~m}$ 이며 줄기는 원기둥 모양이고 밑동은 뿌리 모양을 하고 있는 감태는 일본에서도 서식하는 것으로 알려져 있는데, 식용해조류로서 항산화성, 항암성, 항고혈압성 등 여 러 가지 기능성들이 밝혀져 있으므로 새로운 기능성 소재로서 충분한 가치가 있음이 보고되고 있다[10,22]. 특히, 감태의 주 요 성분인 phlorotannin은 phloroglucinol을 기본 구성단위로 하는 폴리페놀화합물로 phlorotannin 생리활성에 관한 연구 로는 혈전생성 저해활성, 항산화활성, 심혈관 보호효과, 및 항 바이러스활성 등이 보고된 바가 있다[1,12,13]. 하지만, 지금까 지 감태 열수 추출물의 생리활성 분석에 대한 연구는 전무한 상황인데, 이 연구를 통해 식생활에서 감태를 물에 끓여 먹었 을 때 그 효능을 예상할 수 있을 것으로 판단된다.

따라서, 본 연구에서는 감태의 생리활성을 좀 더 상세히 알아보기 위해 감태 열수 추출물의 항산화능, 아질산 소거 능 및 elastase 저해효과에 대해 조사함으로써 해조류 기능 성 소재개발의 기초자료로 제시하고자 한다. 특히, 해조류의 알코올 대사효능에 대해서는 지금까지 보고되어 있지 않으 므로 본 연구에서 숙취해소 소재로써 감태의 가치를 제시하 고자 한다. 


\section{재료 및 방법}

\section{시료}

본 실험에 사용한 감태(E. cava Kjellman)는 제주 해초식품 에서 구입하여 깨끗이 씻은 후 일주일 동안 음지에서 자연 건조 시켰다. 이후 믹서기(HMF-1000A, Hanil Electronics, Korea)로 분쇄한 감태 시료 $50 \mathrm{~g}$ 에 증류수 11 를 가하고, $90^{\circ} \mathrm{C}$ 에서 12시간 동안 추출하였다. 추출한 다음은 Whatman No. 2 filter paper로 여과한 후 rotary evaporator (EYELA N-1000, Rikakikai CO., LTD., Tokyo, Japan)에서 농축하고 다시 $-70^{\circ} \mathrm{C}$ 에서 동결건조한 것을 시료로 사용하였다. 각 생리활성 측정 시 시료는 증류수에 농도별로 용해한 후 측정하였다.

\section{$\mathrm{DPPH}$ 라디칼 소거능 측정}

감태 열수 추출물의 전자공여능은 Blois의 방법[2]에 따라 DPPH (1,1-Diphenyl-2-picrylhydrazyl)에 대한 수소공여 효과 로 측정하였다. DPPH 용액은 $100 \mathrm{ml}$ 에탄올에 DPPH $1.5 \times 10^{4}$ $\mathrm{M}$ 을 녹인 후 증류수 $100 \mathrm{ml}$ 혼합하여 Whatman filter paper No. 2로 여과하여 만들었다. 96 well plate에 시료와 DPPH용 액을 $1: 4$ 비율로 혼합하여 $37^{\circ} \mathrm{C}$ 에서 30 분간 반응시킨 후, ELISA reader를 이용하여 $520 \mathrm{~nm}$ (Molecular Device, VersaMax Microplate Reader, Calfornia, USA)에서 흡광도를 측정하였 다. 전자공여능(Electron donating ability, $\mathrm{EDA})$ 은 $\mathrm{EDA}(\%)=$ (대조구흡광도-시료첨가구흡광도)/대조구흡광도× 100 으로 계 산하였다. 시료를 첨가하지 않은 대조그룹과 흡광도차를 비교 하여 라디칼의 제거활성을 백분율로 나타내었다.

\section{SOD 유사활성(Superoxide dismutase-like activity: SODA) 측정}

SOD 유사활성은 Marklund와 Marklund의 방법[23]에 따라 활성 산소종을 과산화수소 $\left(\mathrm{H}_{2} \mathrm{O}_{2}\right)$ 로 전환시키는 반응을 촉매 하는 pyrogallolo의 생성량을 측정하여 나타내었다. 시료를 농 도별로 희석하여, $10 \mu 1$ 씩 96 well plate에 첨가한 후, Tris- $\mathrm{HCl}$ Buffer (50 mM Tris aminomethane, $10 \mathrm{mM}$ EDTA, pH 8.0) $150 \mu \mathrm{l}$ 와 $7.2 \mathrm{mM}$ pyrogallol $10 \mu \mathrm{l}$ 을 첨가하여, 실온에서 10 분 간 반응시키고, $1 \mathrm{~N} \mathrm{HCl} 50 \mu \mathrm{l}$ 을 첨가하여 반응을 정지시킨 후 ELISA reader를 사용하여 $420 \mathrm{~nm}$ 에서 흡광도를 측정하였 다. SOD 유사활성은 시료 첨가구와 무첨가구 사이의 흡광도 차이를 백분율 $(\%)$ 로 나타내었다.

$$
\operatorname{SODA}(\%)=\left(1-\frac{A}{B}\right) \times 100
$$

$\mathrm{A}$ : 시료 첨가구의 흡광도, $\mathrm{B}$ : 시료 무첨가구의 흡광도

\section{Xanthine oxidase 억제 활성}

Xanthine oxidase 저해활성측정은 $50 \mathrm{mM}$ phosphate buffer (pH 7.5)에 xanthine $2 \mathrm{mM}$ 을 녹인 기질액 $1 \mathrm{ml}$ 에 효소액
$0.1 \mathrm{ml}$ 와 시료 $0.1 \mathrm{ml}$ 를 첨가하여 반응구로 하였으며, 대조구 는 시료 대신 증류수를 $0.1 \mathrm{ml}$ 첨가하여 $37^{\circ} \mathrm{C}$ 에서 5 분간 반응 시킨후 $20 \% \mathrm{TCA} 1 \mathrm{ml}$ 를 첨가하여 반응을 종료시키고 3,000 $\mathrm{rpm}$ 에서 10 분 동안 원심분리하여 단백 질을 제거한 후 반응액 중에 생성된 uric acid를 흡광도 $292 \mathrm{~nm}$ 에서 측정하였다. 효소 의 저해율은 동일농도로 3회씩 반복 시험한 후 반응액 중에 생성된 uric acid의 평균값을 백분율로서 나타내었다[33].

\section{아질산염 소거능 측정}

감태 열수 추출물의 아질산염 소거능은 Gray와 Dugan의 방법[6]을 변형하여 측정하였다. 즉, 아질산염 용액에 시료 용 액을 가하고 여기에 $0.1 \mathrm{~N} \mathrm{HCl}(\mathrm{pH} 1.2)$ 및 $0.2 \mathrm{M}$ 구연산 완충 용액 $(\mathrm{pH} \mathrm{3.0와} \mathrm{6.0)을} \mathrm{사용하여} \mathrm{반응} \mathrm{용액의} \mathrm{pH}$ 를 각각 1.2 , 3.0 및 6.0 으로 조정하여 반응용액을 준비하였다. 이를 $37^{\circ} \mathrm{C}$ 에 서 1 시간 동안 반응시킨 다음 Griess 시약을 가하여 혼합시켜 15 분간 실온에 방치시킨 후, $520 \mathrm{~nm}$ 에서 흡광도를 측정하여 잔존하는 아질산염을 구하였다. 아질산염 소거능은 다음식에 따라 계산하였다.

아질산염 소거율 $(\%)=[1-(\mathrm{A}-\mathrm{C}) / \mathrm{B}] \times 100$

$\mathrm{A}: 1 \mathrm{mM} \mathrm{NaNO} 2$ 용액에 추출 시료를 첨가하여 1시간 반응 시킨 후의 흡광도

B: $\mathrm{NaNO}_{2}$ 용액의 흡광도

$\mathrm{C}$ : 추출시료 자체의 흡광도

\section{$\mathrm{ADH}$ 활성 측정}

$\mathrm{ADH}$ 활성도는 Choi 등[4]과 Racker의 방법[30]을 변형하였 는데, spectrophotometer를 이용하여 $340 \mathrm{~nm}$ 에서 형성되는 $\mathrm{NADH}$ 의 흡광도를 측정함으로써 나타내었다. 즉, 시험관에 alcohol, NAD 수용액, 시료 $0.1 \mathrm{ml}$ 를 첨가하고 $0.01 \mathrm{M}$ glycine- $\mathrm{NaOH}$ 완충용액 $(\mathrm{pH}$ 8.8)을 총 부피가 $1.8 \mathrm{ml}$ 가 되게 첨가 한 후 $25^{\circ} \mathrm{C}$ 항온수조에서 10 분간 반응시키고 $\mathrm{ADH}(10$ $\mathrm{unit} / \mathrm{ml}$ )를 가하여 $340 \mathrm{~nm}$ 에서 흡광도의 변화를 측정하였다. 이때 대조구는 시료대신 증류수를 넣은 것으로 하였다. Positive control로 사용한 hepos는 약국에서 구입한 것으로, 처방전에 따라 $1 / 2$ 로 희석하여 사용하였다. $\mathrm{ADH}$ 의 활성은 반응 종료시의 최대 흡광도를 대조구의 최대 흡광도에 대한 비율로 나타내었으며 다음과 같은 식으로 계산하였다.
$\mathrm{ADH}$ activity $=(\mathrm{B} / \mathrm{A}) \times 100$
$\mathrm{A}$ : 대조구의 최대 흡광도
$\mathrm{B}$ : 실험구의 최대 흡광도

\section{$\mathrm{ALDH}$ 활성 측정}

$\mathrm{ALDH}$ 의 활성도는 Tottmar 등의 방법[34]을 변형하여 $\mathrm{NADH}$ 생성에 따른 흡광도의 변화를 $340 \mathrm{~nm}$ 에서 측정하였 다. 즉, $\mathrm{ALDH}$ 의 활성도 측정을 위해 증류수, $1 \mathrm{M}$ Tris- $\mathrm{HCl}$ 
buffer (pH 7.5), $3 \mathrm{M} \mathrm{KCl}$, 시료, $20 \mathrm{mM}$ NAD, $0.33 \mathrm{M}$ 2-mercaptoethanol, $0.1 \mathrm{M}$ acetaldehyde를 혼합한 다음 $25^{\circ} \mathrm{C}$ 에서 10 분간 반응시키고 $\mathrm{ALDH}(1 \mathrm{unit} / \mathrm{ml})$ 를 가하여 $340 \mathrm{~nm}$ 에서 흡광도의 변화를 측정하였다. 이때 대조구는 시료대신 증류수 를 넣은 것으로 하였다. Positive control은 $\mathrm{ADH}$ 활성 영향 측정에서 사용한 것으로 하였으며, $\mathrm{ALDH}$ 의 활성은 $\mathrm{ADH}$ 활 성 계산식에 따라 측정 되었다.

\section{Tyrosinase 저해활성 측정}

시료의 tyrosinase 활성 저해능은 Yagi의 방법[36]에 따라 측정하였다. 즉, $50 \mathrm{mM}$ sodium phosphate buffer ( $\mathrm{pH}$ 6.5), 기질인 $2 \mathrm{mM} \mathrm{L-tyrosine} \mathrm{용액} \mathrm{및} \mathrm{시료} \mathrm{용액의} \mathrm{혼합액에} \mathrm{mush-}$ room tyrosinase $(1,000 \mathrm{unit} / \mathrm{ml})$, 초순수를 첨가하여 $25^{\circ} \mathrm{C}$ 에 서 30 분간 반응시킨 다음 $490 \mathrm{~nm}$ 에서 흡광도 값 $\left(\mathrm{S}_{\mathrm{Abs}}\right)$ 을 측정 하였다. 이때 효소액 대신에 $50 \mathrm{mM}$ sodium phosphate buffer $\left(\mathrm{pH}\right.$ 6.5) $20 \mu \mathrm{l}$ 를 첨가하여 흡광도를 측정한 값( $\left(\mathrm{B}_{\mathrm{Abs}}\right)$, 시료 용 액 대신에 증류수를 $10 \mu \mathrm{l}$ 를 첨가하여 흡광도를 측정한 값 $\left(\mathrm{C}_{\mathrm{Abs}}\right)$ 을 다음의 식에 의해 계산하였다.

$$
\begin{aligned}
& \text { 저해율 }(\%)=\left[1-\left(\mathrm{S}_{\mathrm{Abs}}-\mathrm{B}_{\mathrm{Abs}}\right) / \mathrm{CAbs}\right] \times 100 \\
& \mathrm{~S}_{\mathrm{Abs}} \text { : Sample absorbance } \\
& \mathrm{B}_{\mathrm{Abs}}: \text { Blank absorbance } \\
& \mathrm{C}_{\mathrm{Abs}} \text { : Control absorbance }
\end{aligned}
$$

\section{Elastase 저해활성 측정}

시료의 elastase 저해활성은 James의 방법[9]에 따라 측정하 였다. 즉, $0.05 \mathrm{M}$ Tris- $\mathrm{HCl}$ buffer (pH 8.2)에 기질인 $0.5 \mathrm{mM}$ N-succinyl-Ala-Ala-Ala-pnitroniline를 용해시킨 후 시료와 효소인 elastase $(1 \mathrm{unit} / \mathrm{ml})$ 용액을 첨가하였다. 이 혼합액을 $25^{\circ} \mathrm{C}$ 에서 10 분간 반응시킨 후 $415 \mathrm{~nm}$ 에서 흡광도를 측정하였 다. Elastase 저해활성은 다음의 식에 의해 계산하였다.

$$
\begin{aligned}
& \text { 저해활성 }(\%)=[1-\mathrm{S} / \mathrm{C}] \times 100 \\
& \mathrm{~S} \text { : 시료 첨가구의 흡광도 } \\
& \mathrm{C}: \text { 무첨가구의 흡광도 }
\end{aligned}
$$

\section{통계분석}

본 실험에서 얻은 결과는 각 시료마다 세 번씩 반복 실험을 통해 실험군당 평균과 표준편차를 계산하여 나타내었다.

\section{결과 및 고찰}

\section{$\mathrm{DPPH}$ 에 의한 항산화 활성}

인체 내의 free radical은 지질, 단백질 등과 반응하여 생체의 노화를 촉진할 수 있는 물질로, 이러한 free radical를 제거할 수 있는 천연물질에 대한 연구가 활발히 진행되고 있다. 특히 DPPH (1,1-diphenyl-2-picrylhydrazyl) radical 소거법은 항산
화물질의 전자공여능을 이용한 항산화 측정법으로써 주로 phenolic 구조와 aromatic amine 화합물에서 많이 사용되는 방법이다.

감태 열수 추출물의 항산화 효과를 DPPH radical 제거 정도 를 측정하여 전자공여능으로 나타낸 결과 $0.5 \mathrm{mg} / \mathrm{ml}$ 농도에 서 73.7\%였다(Fig. 1). 이를 positive control로 사용한 0.1 $\mathrm{mg} / \mathrm{ml}$ 의 $\mathrm{BHA}(73 \%)$ 와 비교해 볼 때 적지 않은 항산화 활성 을 나타내고 있고, 또한 추출물의 농도가 증가함에 따라 그 활성이 증가하기 때문에 높은 DPPH radical 소거능을 기대할 수 있다. 즉, $1 \mathrm{mg} / \mathrm{ml}$ 의 감태 열수 추출물이 $91.4 \%$ 로 높은 활성을 보였는데 $2 \mathrm{mg} / \mathrm{ml}$ 의 감태 메탄올 추출물의 활성 $85 \%$ 와 효소적 추출물의 활성 $90 \%$ 보다 높게 나타났다[21]. Lee 등[21]은 감태 메탄올 추출물의 폴리페놀 함량이 효소적 추출 물보다 훨씬 높지만, DPPH radical 소거능은 낮게 나타나고 있음을 보고하였는데, 지금까지 보고된 DPPH radical 소거능 과 페놀성 화합물과의 긍정적 상관관계와는 상반되는 것이다 [26,32]. 이는 효소적 추출물에 페놀성분 뿐만 아니라 다른 활 성성분들이 항산화효과에 영향을 끼친 것으로 보고 있는데, 본 연구결과인 감태 열수 추출물의 높은 DPPH radical 소거능 도 이와 유사한 근거로 보아진다.

\section{SOD 유사활성(Superoxide dismutase-like activity: SODA)}

Superoxide dismutase (SOD)는 항산화 효소로서 세포에 유 해한 oxygen radical을 과산화수소로 전환시키고 다시 catalase에 의하여 무해한 물 분자와 산소분자로 전환시켜 활성산 소로부터 생체를 보호하는 기능으로 알려져 있다. SOD는 분 자량이 비교적 큰 단백질로서 열이나 알칼리에 약하여 이러한 단점을 보완할 수 있는 저분자물질로 체내에서 역할이 유사한 $\mathrm{SOD}$ 유사활성 물질에 대한 연구가 진행되고 있다. SOD 유사

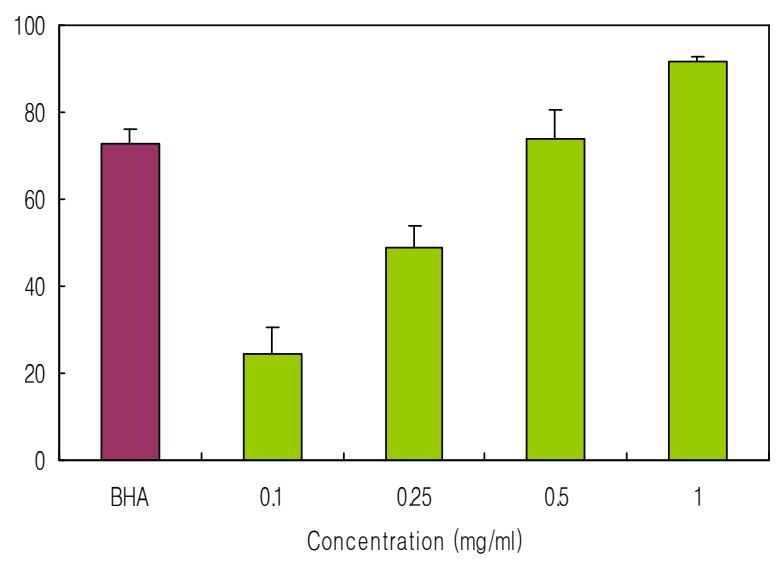

Fig. 1. DPPH free radical scavenging activity of hot water extract from Ecklonia cava (ECE). Results are mean \pm S.D. of triplicate data. BHA (butylated hydroxy anisole, $0.1 \mathrm{mg} / \mathrm{ml}$ ) was used as positive control. 
활성 물질은 효소는 아니지만 SOD와 유사한 역할을 하는 저 분자 물질로 주로 phytochemical에 속하며 superoxide의 반응 성을 억제하여 항산화력을 나타내는 것으로 밝혀져 있다.

본 연구에서 감태 열수 추출물의 $\mathrm{SOD}$ 유사활성은 농도 의 존적으로 증가하였는데, $1 \mathrm{mg} / \mathrm{ml}$ 에서 $75.0 \%$ 로 나타났으며 positive control로 사용한 $0.5 \mathrm{mg} / \mathrm{ml}$ 의 $\operatorname{VitC}(93.6 \%)$ 와의 비 교에서 보는 바와 같이 높은 활성을 나타내고 있다(Fig. 2). 이 결과는 높은 항산화능으로 널리 알려져 있는 녹차의 열수 와 에탄올 추출물보다 높은 것으로 감태의 항산화제로써의 가치를 높이 평가할 수 있다[20]. 또한 본 연구결과는 감태 butanol 분획물의 SOD 유사활성보다 우수한 것으로 보여지고 있는데 Kim과 Lee [14]의 보고에 의하면 감태 유기용매 분획 물 중 butanol 분획물이 가장 우수한 활성을 나타냈다. 따라서, 높은 SOD 유사활성으로 항산화능을 나타내는 감태 열수 추출 물이 항산화 소재로써 활용성이 높을 것으로 예상된다.

\section{Xanthine oxidase 저해활성}

Xanthine oxidase는 purine 대사에 관여하는 효소로서 xanthine 또는 hypoxanthine의 산소를 때어내면서 과산화수소 $\left(\mathrm{H}_{2} \mathrm{O}_{2}\right)$ 를 생성하게 하여, 나머지 골격이 uric acid를 형성하여 혈장 내에 과량 존재하게 되면 골절에 축적되어 심한 통증을 유발하는 통풍과 신장에 침착되어 신장질환을 일으키는 효소 로 알려져 있다. Xanthine oxidase 저해활성 측정은 일종의 항산화 능을 측정하는 방법으로 본 실험에서는 대조구로 catechin을 사용하였으며 감태 열수 추출물과 농도별로 비교하였 다. Xanthine oxidase저해 활성 측정 결과 $0.5,1,1.5,2 \mathrm{mg} / \mathrm{ml}$ 의 각 농도에 따라 저해활성이 증가하였으며, 대조구인 catechin 농도 $1 \mathrm{mg} / \mathrm{ml}$ 에서의 활성 $79 \%$ 와 비교해 보면 $1 \mathrm{mg} / \mathrm{ml}$ 감태 열수 추출물의 활성이 $70 \%$ 로 catechin과 비슷한 수준의

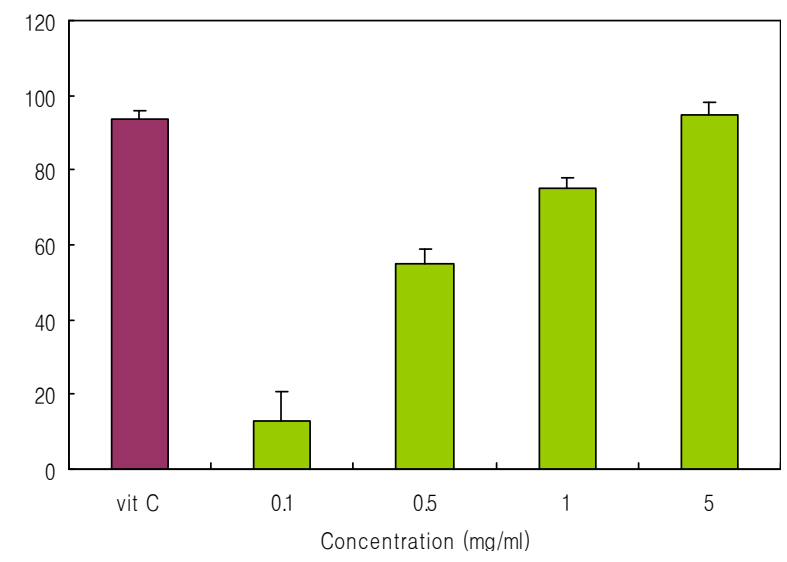

Fig. 2. Superoxide dismutase (SOD)-like activity of hot water extract from Ecklonia cava (ECE) depending on concentration. Results are represented as means \pm S.D. of three independent experiments. VitC, vitamin C $(0.5$ $\mathrm{mg} / \mathrm{ml})$.
높은 저해활성을 나타내었다(Fig. 3). Catechin은 polyphenol 계 항산화 물질로써 식물성 대사산물로 알려져 있으며 항산화 효과가 비타민 E에 비해 무려 50배나 되고, 비타민 C에 비해 100 배에 달하기 때문에, 체내의 활성산소를 제거하는 효과가 매우 탁월하다고 알려져 있다[31]. 이러한 catechin의 효과와 유사한 결과를 나타내고 있는 감태 열수 추출물은 우수한 항 산화 소재로 개발할 수 있을 것으로 기대된다. 또한, 지금까지 감태의 XOase 저해효과에 대해 보고되어 있지 않으므로 본 연구결과의 가치가 높다고 판단된다.

\section{아질산염 소거능}

아질산염은 단백 질 식품이나 의약품 및 잔류 농약 등에 존 재하는 2 급, 3 급 등의 아민류와 반응하여 니트로사민을 생성 하며, 위내에서 발암성 물질로 작용한다[26]. 그러므로 산성 영역에서 니트로사민의 생성인자인 아질산염을 효과적으로 소거하여 니트로사민의 생성을 억제하는데 기여하는 물질들 을 찾고자 연구되어 왔다. 이에 본 연구에서는 감태 열수 추출 물이 아질산염 소거능에 미치는 영향을 $\mathrm{pH}$ 별, 농도별로 분석 하였는데 $\mathrm{pH}$ 별로는 1.2, 3.0, 6.0으로 하였으며, 농도별로는 positive control인 $\mathrm{VitC}$ 와 감태 열수 추출물을 $0.1,0.5,1$ $\mathrm{mg} / \mathrm{ml}$ 로 하였다. 그 결과 $\mathrm{pH}$ 가 낮을수록 시료농도가 높을수 록 $\mathrm{VitC}$ 와 감태 열수 추출물의 아질산염 소거능이 증가하였다 (Fig. 4). 즉, $\mathrm{pH} 1.2$ 인 경우 $0.1 \sim 1 \mathrm{mg} / \mathrm{ml}$ 의 $\mathrm{VitC}$ 와 감태 열수 추출물은 각각 $62.6 \sim 89.3 \%$ 와 $72.8 \sim 93.6 \%$ 의 아질산염 소거능 을 보였으며, $\mathrm{pH} 3.0$ 에서는 각각 $40.4 \sim 81.0 \%$ 와 $41.0 \sim 68.5 \%$ 로 나타났으며, $\mathrm{pH} 6.0$ 에서는 각각 $25.5 \sim 42.5 \%$ 와 $24 \sim 41.7 \%$ 였다(Fig. 4). 감태 열수 추출물과 VitC 모두 $\mathrm{pH}$ 가 낮은 조건에 서 높은 아질산염 소거능을 보였으며, 특히, $\mathrm{pH} 1.2$ 에서 감태 열수 추출물의 경우 $\mathrm{VitC}$ 보다 약간 높은 아질산염 소거능을 나타내었다. Park 등[25]에 의하면 $\mathrm{pH} 1.2$ 에서 같은 농도의 곰피, 미역, 다시마, 지충이, 모자반, 톳, 김, 도박, 꼬시래기,

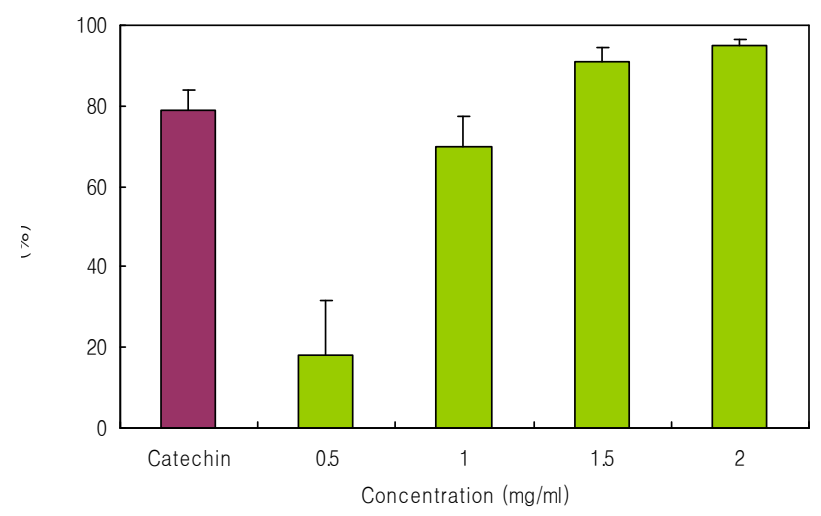

Fig. 3. Xanthine oxidase inhibitory activity of hot water extract from Ecklonia cava (ECE) depending on concentration. Results are mean \pm S.D. of triplicate data. Catechin (1 $\mathrm{mg} / \mathrm{ml}$ ) is used as positive control. 


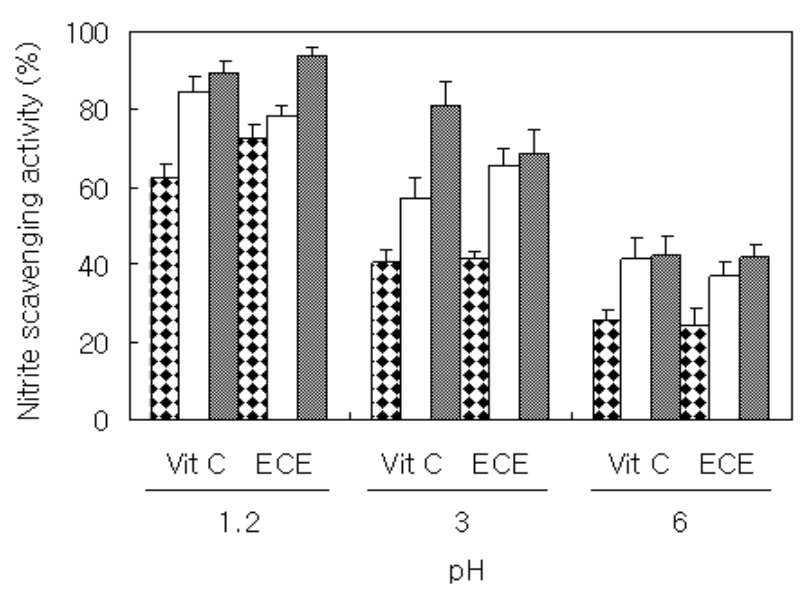

Fig. 4. Nitrite scavenging effect of hot water extracts from Ecklonia cava (ECE) under different $\mathrm{pH}$ conditions. $\mathbf{\nabla}$, $0.1 \mathrm{mg} / \mathrm{ml}$ of VitC or ECE; $\square, 0.5 \mathrm{mg} / \mathrm{ml}$ of VitC or ECE; $1 \mathrm{mg} / \mathrm{ml}$ of $\mathrm{VitC}$ or ECE. Results are mean \pm S.D. of triplicate data.

청각, 파래, 마디잘룩이등의 아질산염 소거능과 비교한 결과 감태가 가장 높은 효능을 나타내었는데, $1 \mathrm{mg} / \mathrm{ml}$ 의 감태 메 탄올 추출물이 $90 \%$ 의 아질산염 소거능을 보였다. 이들 보고 와 비교 분석한 결과 본 연구의 감태 열수 추출물과 유사한 효능을 나타내고 있는데 이는 감태의 탄닌성분들 외에도 다 른 성분들의 효능으로 추측된다. 본 연구결과는 아질산염 억 제제로 잘 알려져 있는 대조군 $\mathrm{VitC}$ 보다 높게 나타나고 있어 천연의 안전한 항염증 소재로써 감태 열수 추출물의 이용가 능성을 확인 할 수 있었다. 특히, 인체의 위 내 $\mathrm{pH}$ 조건과 비 슷한 $\mathrm{pH} 1.2$ 에서 활성이 좋은 것으로 확인되고 있으므로 식 품에 직접 활용할 수 있는 우수한 기능성 소재로써 그 가치 가 기대된다.

\section{$\mathrm{ADH}$ 및 $\mathrm{ALDH}$ 활성 영향}

감태 열수 추출물에 의한 숙취 해소능을 생화학적으로 분석 하기 위해 체내 알콜 대사의 1 차 관여 효소인 $\mathrm{ADH}$ 의 활성 증진 정도를 측정하였다. 또한 숙취의 주 원인물질인 acetaldehyde는 체내에서 흡수된 알코올이 분해 시 생성되는 대사산 물로서 단순히 $\mathrm{ADH}$ 만 활성화 시키면 혈중 알콜 농도는 빠르 게 감소시킬 수 있으나 간이나 혈액에 남아있는 acetaldehyde 는 계속 축적이 되어 심한 숙취를 일으킬 수 있는 가능성이 있다. 따라서, acetaldehyde의 분해에 직접적인 영향을 미치는 효소인 $\mathrm{ALDH}$ 의 활성에 감태 열수 추출물이 미치는 영향을 분석하였다. 감태 열수 추출물의 $\mathrm{ADH}$ 및 $\mathrm{ALDH}$ 의 활성에 미치는 효과는 반응 후의 최대 흡광도와 효소의 반응 속도를 통하여 분석하였으며, 그 결과는 Fig. 5 와 Fig. 6 에 나타낸 바와 같다. 최대 흡광도는 모든 실험구에서 유의적인 차이를 나타 냈으며 대조구의 흡광도의 값을 100 으로 하였을 때 감태 열수

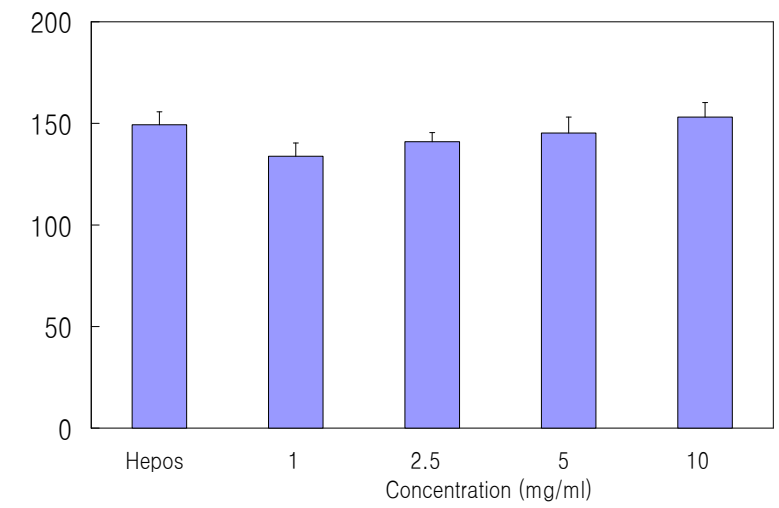

Fig. 5. Effects of hot water extracts from Ecklonia cava on the alcohol dehydrogenase (ADH) activity. Results are mean \pm S.D. of triplicate data. Hepos is used as positive control.

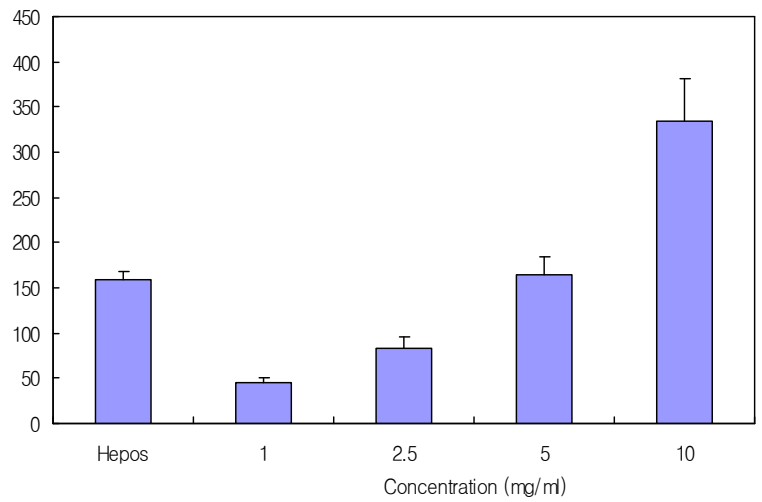

Fig. 6. Effects of hot water extracts from Ecklonia cava on the aldehyde dehydrogenase (ALDH) activity. Results are mean \pm S.D. of triplicate data. Hepos is used as positive control.

추출물을 첨가한 경우 $\mathrm{ADH}$ 활성이 증가하였다. 즉, 감태 열수 추출물 농도 $10 \mathrm{mg} / \mathrm{ml}$ 에서 $\mathrm{ADH}$ 활성 촉진율은 $153 \%$ 로 positive control (hepos) 149\% 보다 높게 나타났으며, 감태 열수 추출물의 농도가 증가함에 따라 $\mathrm{ADH}$ 활성율은 증진하였다. $\mathrm{ALDH}$ 활성 촉진율에 있어서도 감태 열수 추출물은 높은 효 능을 나타내었다. 즉, 대조구의 흡광도 값을 100 으로 하였을 때 감태 열수 추출물을 첨가한 경우, 농도 증가에 따른 $\mathrm{ALDH}$ 활성 촉진율의 변화는 크게 나타났으며, positive control (hepos)의 ALDH 활성 촉진율 $160 \%$ 보다 높은 효능을 보였다 (Fig. 6). 즉, 감태 열수 추출물 $5 \mathrm{mg} / \mathrm{ml}$ 에서 positive control과 유사한 ALDH 활성 촉진율 $(164 \%)$ 을 나타내었고, $10 \mathrm{mg} / \mathrm{ml}$ 에 서는 $334 \%$ 의 큰 효능을 보였다. Hwang 등[8]의 보고에 의하 면 $10 \% \mathrm{GMT}$ 에서 $\mathrm{ADH}$ 활성 촉진율이 $153.0 \%$ 이었으며, $1 \%$ 아스파르트산의 경우 $144.3 \%$ 로 나타났다. GMT는 쌀배아추출 물인 구루메로써 아스파르트산과 함께 숙취해소 효과가 있는 
것으로 알려져 있다. Kim 등[16]의 보고에 의하면 in vivo 실험 에서 알콜 분해와 숙취에 효과가 있는 것으로 알려진 헛개나 무 추출물을 이용하여 분석한 결과 대조군보다 헛개나무 추출 물의 $\mathrm{ADH}$ 활성 증진이 $8-14 \%$ 정도 상승한 것으로 나타났으 나 그다지 높지 않은 반면, $\mathrm{ALDH}$ 의 활성 증진은 대조군 보다 $18-24 \%$ 정도 더 높게 나타났다. 이는 헛개나무가 $\mathrm{ADH}$ 활성 증진에 의한 알콜 분해도 촉진시키지만 $\mathrm{ALDH}$ 의 활성을 좀 더 증진 시키므로 빠르게 acetaldehyde를 acetic acid로 분해시 켜서 숙취해소에 상당한 도움을 주는 것으로 밝혀졌다. 이들 보고와 비교해 볼 때 감태 열수 추출물은 알콜과 acetaldehyde 분해능을 동시에 가질 뿐만 아니라 ALDH 활성을 훨씬 더 증진시키므로 숙취해소 효과가 상당히 클 것으로 사료된다. 또한 지금까지 해조류의 숙취해소작용에 대해 보고된 바가 없으므로 본 연구결과인 감태 열수 추출물의 높은 알코올, 알 데히드 분해능에 대한 보고는 숙취해소 소재개발에 있어서 그 가치가 상당할 것으로 판단된다.

\section{Tyrosinase 저해효과}

Tyrosinase는 멜라닌 합성의 초기단계인 L-tyrosine에서 L-3,4-dihydroxy-phenylalanine (DOPA)를 거쳐 L-dopaquinone으로의 전환에 관여하며 최종적으로 melanin 색소 생성에 관여하는 효소이다. 특히 피부는 자외선에 노출되면서 tyrosinase의 작용으로 melanosome에서 멜라닌이 합성되어 피부노화가 촉진되며, 색소침착과 피부 흑화 현상의 원인이 된다. 따라서 tyrosinase 활성저해제는 의약품, 화장품 등에 널리 적용되며, 인체에 부작용이 적은 천연소재를 확보하기 위한 연구가 집중되고 있다[15]. 잘 알려진 tyrosinase 활성저 해제로는 aromatic aldehyde, aromatic acids, tropolone 및 kojic acid 등이 있다.

본 연구에서는 melanin 색소 생성에 관여하는 tyrosinase에

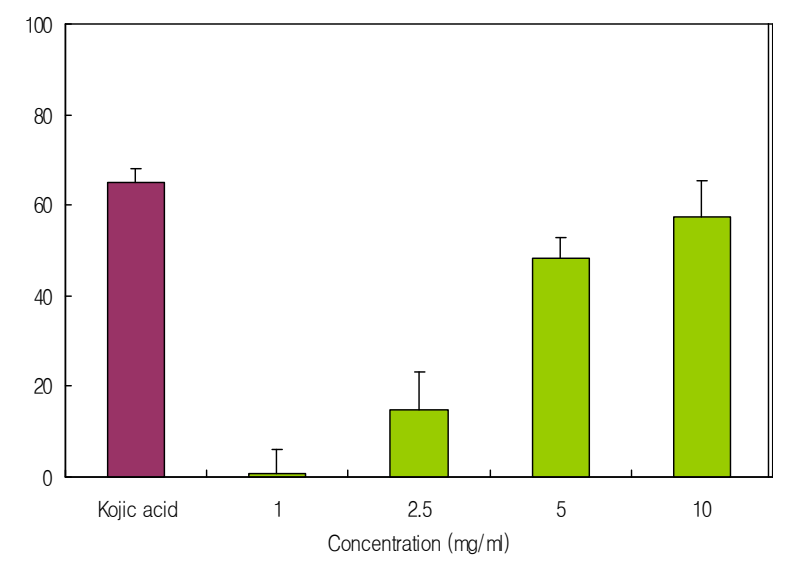

Fig. 7. Tyrosinase inhibitory effect of hot water extracts from Ecklonia cava depending on concentration. Results are mean \pm S.D. of triplicate data. Concentration of kojic acid as positive control is $0.1 \mathrm{mg} / \mathrm{ml}$.
대한 감태 열수 추출물의 농도별 저해효과를 나타내었다(Fig. 7). Positive control로 사용한 kojic acid는 $0.1 \mathrm{mg} / \mathrm{ml}$ 의 농도 에서 $65 \%$ 의 tyrosinase 억제효과를 나타낸 반면, 감태 열수 추출물의 경우 $10 \mathrm{mg} / \mathrm{ml}$ 의 농도에서 $58 \%$ 의 저해효능을 보였 다. 비록, 그 효능이 충분히 높지는 않지만 감태 열수 추출물의 농도가 증가함에 따라 tyrosinase 저해활성이 증가하므로 충 분한 미백효능을 기대할 수 있을 것으로 판단된다. Park 등[27] 에 의하면 곰피 메탄올 추출물을 제외하고는 미역, 모자반, 김, 꼬시래기, 도박, 청각, 구멍갈파래, 우뭇가사리등 14 종의 해조류 메탄올 추출물 중에서 감태가 가장 높은 효능을 나타 내었는데 감태 메탄올 추출물 $10 \mathrm{mg} / \mathrm{ml}$ 에서 $72 \%$ 의 tyrosinase 억제효과를 보고하였다. 이들 보고와 비교 분석한 결 과 본 연구의 감태 열수 추출물보다 높은 효능을 나타내고 있는데 이는 감태의 메탄올 추출에 의해 수용성인 다당류보다 탄닌성분 추출이 더 용이하였을 것이므로 감태의 미백효능은 다당류보다 탄닌성분들의 효능으로 추측된다. 이로써, 감태의 미백효능에 대해서 메탄올 및 에탄올 추출이 더 효율적일 것 으로 사료되지만 이들 용매를 이용한 추출물의 안전성을 고려 해 보면 미백효능을 충분히 나타내고 있는 감태 열수 추출물 이 미용 식품 소재로 활용하는데 있어 그 가치가 높을 것으로 판단된다.

\section{Elastase 저해활성}

Elastase는 진피 내 피부탄력을 유지하는 기질 단백질인 elastin의 분해에 관여하며[5], collagen을 분해할 수 있는 비특 이적 가수분해 효소이다. 또한 체내의 elastin을 분해하는 백혈 구 과립 효소 중의 하나로 이상조직에서는 활성이 높아져 조 직파괴의 직접적인 원인이 되며, 피부의 주름 및 탄력성 소실 등을 유발한다[5]. 따라서, elastase 저해제는 피부의 주름을 개선하는 효과가 있다[35].

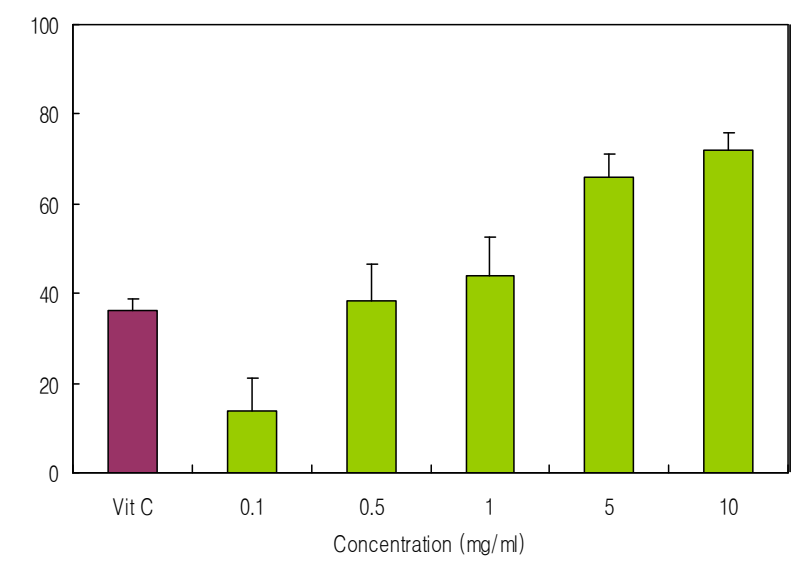

Fig. 8. Elastase inhibitory effect of hot water extracts from Ecklonia cava depending on concentration. Results are mean \pm S.D. of triplicate data. Concentration of VitC as positive control is $1 \mathrm{mg} / \mathrm{ml}$. 
본 연구에서 감태 열수 추출물의 elastase 저해활성을 조사 한 결과는 Fig. 8과 같다. 전반적으로 농도가 높아짐에 따라 비례적으로 저해활성이 증가하였는데, 감태 열수 추출물 0.5 $\mathrm{mg} / \mathrm{ml}$ 에서 $38 \%, 1 \mathrm{mg} / \mathrm{ml}$ 에서 $44 \%$ 의 저해활성이 나타났 다. Positive control로 elastase 저해 활성 효과가 알려진 $\mathrm{VitC}$ 는 $1 \mathrm{mg} / \mathrm{ml}$ 의 농도에서 $36 \%$ 의 저해활성이 나타났다. 또한 elastase 활성저해제인 oleanolic acid는 농도 0.5 $\mathrm{mg} / \mathrm{ml}$ 에서 elastase를 $32 \%$ 정도 저해하는 것으로 알려져 있 다[17,24,37]. 감태에 있어서 elastase 억제 효과에 대해서는 $\mathrm{Bu}$ 등[3]에 의해서도 보고된 바가 있는데 이는 본 연구 결과 를 뒷받침하고 있는 것으로 감태 열수 추출물의 피부 주름 개선 효과를 증명하고 있다. 또한, 감태 열수 추출물에서 elastase 저해 활성이 elastase 저해제로 잘 알려져 있는 대조 군과 유사하게 나타나고 있어 천연 주름 억제제로서의 이용 가능성을 확인 할 수 있었다.

\section{References}

1. Ahn, M. J., K. D. Yoon, S. Y. Min, J. S. Lee, J. H. Kim, T. G. Kim, S. H. Kim, N. K. Kim, H. Huh, and J. W. Kim. 2004. Inhibition of HIV-1 reverse transcriptase and protease by phlorotanins from the brown alga Eckonia cava. Biol. Pharm Bull. 27, 544-547.

2. Blois, M. S. 1958. Antioxidant determination by the use of a stable free radical. Nature 26, 1198-1200.

3. Bu, H. J., Y. M. Ham, J. M. Kim, S. J. Lee, J. W. Hyun, and N. H. Lee. 2006. Elastase and hyaluronidase inhibition activities of phlorotannins isolated from Ecklonia cava. Korean J. Pharmacogn. 37, 92-96.

4. Choi, J. T., H. K. Joo, and S. K. Lee. 1995. The effect of Schizandrae fructus extract on alcohol fermentation and enzyme activities of Saccharomyces cerevisiae Agric. Chem Biotechnol. 38, 278-282.

5. Dewitt, D. L., T. Rollins, J. S. Day, J. A. Gauger, and W. L. Smith. 1981. Orientation of the active site, and antigenic determinants of prostaglandin endoperoxide of synthase in the endoplasmic reticulum. J. Biol. Chem 256, 10375-10382.

6. Gray, J. I. and L. R. Dugan Jr. 1975. Inhibition of N-nitrosamine formation in model food systems. J. Food Sci. 40, 981-984.

7. Hsueh, W. A. and P. W. Anderson. 1992. Hypertension, the endothelial cell, and the vascular complications of diabetic mellitus. Hypertension 20, 253-263.

8. Hwang, J. Y., J. W. Ham, and S. H. Nam. 2004. Effect of Maesil (Prunus mume) juice on the alcohol metabolizing enzyme activities. Korean J. Food Sci. Technol. 36, 329-332.

9. James, A. E. K., D. W. Timothy, and L. Gorden. 1996. Inhibition of human leujocyte and porcine pancreatic elastase by homologues of bovine pancreatic tyrosinase inhibitors. Biochem 35, 9090-9096.

10. Jimenez-Escring, A. and I. Goni Cambrodon. 1999. Nutritional evaluation and physiological effects of edible seaweeds. Arch. Latioam Nutr. 49, 114-120.

11. Joung, E. Y. and S. K Lee. 2007. Antioxidant activity and regeneration effect in HaCat cell by Jeju Island aboriginal Ecklonia cava. J. Korean Soc. Cosm 13, 1071-1077.

12. Kang, H. S., H. Y. Chung, J. Y. Kim, B. W. Son, H. A. Jung, and J. S. Choi 2004. Inhibitory phlorotanins from the edible brown alga Ecklonia stolonifera on total reactive oxygen species (ROS) generation. Arch Pharm Res. 27, 194-198.

13. Kang, K., Y. Park, H. J. Hwang, S. H. Kim, J. G. Lee, and H. C. Shin. 2003. Antioxidative properties of brown algae polyphenolics and their perspectives as chemopreventive agents against vascular risk factors. Arch Pharm Res. 26, 286-293.

14. Kim, J. A. and J. M. Lee. 2004. The changes of biologically functional compounds and antioxidant activities in Ecklonia cava with blanching times. Korean J. Food Culture 19, 369-377.

15. Kim, J. W., D. K. Kim, J. S. Park, Y. K. Lee, K. Y. Beik, and S. D. Kim. 2009. Antioxidant and antimicrobial activities of shark collagens, and inhibitory actions on elastase and tyrosinase. Korean J. Food Preserv. 16, 419-426.

16. Kim, M. H., Y. T. Chung, J. H. Lee, Y. S. Park, M. K. Shin, H. S. Kim, D. H. Kim, and H. Y. Lee. 2000. Hepatic detoxification activity and reduction of serum alcohol concentration of Hovenia dulcis $\mathrm{T}_{\mathrm{HUNB}}$ from Korea and China. Korean J. Medicinal Crop Sci. 8, 225-233.

17. Kim, M. K., J. Y. Kim, S. W. Choi, J. T. Hong, and K. S. Yoon. 2004. Anti-wrinkle effect of safflower (Cathamustinctorius) seed extract. J. Soc. Cosmet Sci. Korea 30, 15-22.

18. Kim, S. A., J. Kim, M. K. Woo, C. S. Kwak, and M. S. Lee. 2005. Antimutagenic and cytotoxic effects of ethanol extracts from five kinds of seaweeds. J. Korean Soc. Food Sci. Nutr. 34, 451-459.

19. Kwon, M. J. and T. J. Nam. 2006. Effects of Mesangi (Capsosiphon fulvecens) power on lipid metabolism in high cholesterol fed rats. J. Korean Soc. Food Sci. Nutr. 35, 530-535.

20. Lee, J. H. and S. R. Lee. 1994. Analysis of phenolic substances content of Korea plant foods. Korean J. Food Sci. Technol. 26, 310-316.

21. Lee, S. H., K. N. Kim, S. H. Cha, G. N. Ahn, and Y. J. Jeon. 2006. Comparison of antioxidant activities of enzymatic and methanolic extracts from Ecklonia cava stem and leave. $J$. Korean Soc. Food Sci. Nutr. 35, 1139-1145.

22. Mabeau, S. and J. Fleurence. 1993. Seaweed in food products: biochemical and nutritional aspects. Trends Food Sci. Technol. 8, 22-30.

23. Marklund, S. and G. Marklund. 1975. Involvement of superoxide aminoradical in the oxidation of pyrogallol and a convenient assay for superoxide dismutase. Eur. J. Biochem. 47, 468-474.

24. Nam, K. A. 2007. Characterization of squid sjin collagens and functionality of their enzymatic hydrolysates. pp. 35-36, MS Thesis, University of Kangnung.

25. Nishino, T., Y. Aizu, and T. Nagumo. 1991. The relationship between the molecular weight and the anticoagulant and activity of two types of fucan sulfates from the brown seaweed Ecklonia kurom Agric. Biol. Chem 55, 791-797. 
26. Oki, T., M. Masuda, S. Furuta, Y. Nishibia, N. Terahara, and I. Suda. 2002. Involvement of anthocyanins and other phenolic compounds in radical-scavenging activity of purple-fleshed sweet potato cultivars. J. Food Chem Toxicol. 67, 1752-1756.

27. Park, D. C., C. I. Ji, S. H. Kim, and K. J. Jung. 2000. Characteristics of tyrosinase inhibitory extract from Ecklonia stolonifera. J. Fish Sci. Tech 3, 195-199.

28. Park, Y. B. 2005. Determination of nitrite-scavenging activity of seaweed. J. Korean Soc. Food Sci. Nutr. 34, 1293-1296.

29. Park, Y. B., T. G. Lee, O. K. Kim, J. R. Do, S. G. Yeo, Y. H. Park, and S. B. Kim. 1995. Characteristics of nitrite scavenger derived from seeds of Cassia tora L. Korea J. Food Sci. Technol. 27, 124-128.

30. Racker, E. 1973. Alcohol dehydrogenase in rat liver. Biochem J. 135, 577-581.

31. Ruidavets, J., P. Teissedre, J. Ferrières, S. Carando, G. Bougard, and J. Cabanis. 2000. Catechin in the mediterranean diet: vegetable, fruit or wine? Atherosclero 153, 107-117.

32. Siriwardhana, N., K. W. Lee, S. H. Kim, J. W. Ha, and Y.
J. Jeon. 2003. Antioxidant activity of Hizikia fusiformis on reactive oxygen species scavenging and lipid peroxidation inhibition. Food Sci. Tech Int. 9, 339-346.

33. Stirpe, F. and E. D. Corte. 1969. The regulation of rat liver xanthine oxidase. J. Biol. Chem 244, 3855-3859.

34. Tottmar, S. O., H. Petterson, and K. H. Kiessling. 1973. The subcellular distribution and properties of aldehyde dehydrogenase in rat liver. Biochem J. 135, 577-581.

35. Tsuji, N., S. Moriwaki, Y. Suzuki, Y. Takema, and G. Imokawa. 2001. The role of elastase secreted by fibroblasts in wrinkle formation: implication through selective inhibition of elastase activity. Photochem Photobiol. 74, 283-290.

36. Yagi, A., T. Kanbara, and N. Morinobu. 1987. Inhibition of mushroom tyrosinase by aloe extract. Planta Medica 53, 517-519.

37. Ying, Q. L., A. R. Rinehart, S. R. Simon, and J. C. Cheronis. 1991. Inhibition of human leucocyte elastase by ursolic acid: evidence for a binding site for pentacyclic. Biochem J. 277, 521-526

\section{초록 : 감태 열수 추출물의 생리활성}

조은경 · 최영주 ${ }^{1}$ *

(신라대학교 바이오식품소재학과, ${ }^{1}$ 식품영양학과)

해조류 감태의 기능성을 증명하기 위하여 열수 추출하여 여러 가지 생리활성에 대하여 조사하였다. 우선, 감태 열수 추출물의 항산화능을 조사하기 위하여 DPPH radical 소거능, SOD 유사활성, XO 저해능을 측정하였다. 그 결과 감태 열수 추출물의 농도가 증가 할수록 높은 항산화능이 나타났으며 항산화제로 잘 알려져 있는 BHA, $\mathrm{VitC}$, catechin의 활성보다 높거나 유사하게 보였다. 아질산염 소거능 측정 실험에서 positive control인 VitC와 감태 열수 추출물은 시료농도가 증가할수록 $\mathrm{pH}$ 가 낮을수록 증가하였다. 특히, $\mathrm{pH} 1.2$ 에서 감태 열수 추출물의 경우 $\mathrm{VitC}$ 보다 약간 높은 아질산염 소거능을 나타내었다. 감태 열수 추출물의 숙취해소 효능은 $\mathrm{ADH}$ 와 ALDH 활성증진에 감태 열수 추출물이 미치는 영향을 조사함으로써 증명하고자 하였다. 그 결과, 감태 열수 추출물은 알콜과 acetaldehyde 분해능을 모두 가지고 있을 뿐만 아니라 acetaldehyde의 분해능은 상당히 높게 나타났다. 감태 열수 추출물의 미용효능은 tyrosinase와 elastaase 억제 효과를 분석함으로써 증명하고자 하였다. Tyrosinase 저해능 분석에서 positive control로 사용한 kojic acid는 $0.1 \mathrm{mg} / \mathrm{ml}$ 의 농도에서 $65 \%$ 의 tyrosinase 억제효과를 나 타낸 반면, 감태 열수 추출물의 경우 $10 \mathrm{mg} / \mathrm{ml}$ 의 농도에서 $58 \%$ 의 저해효능을 보였다. 비록, 그 효능이 충분히 높지는 않지만 감태 열수 추출물의 농도가 증가함에 따라서 tyrosinase 저해활성이 증가하므로 충분한 미백효능 을 기대할 수 있을 것으로 판단된다. Elastase 억제 효능 분석에서는 감태 열수 추출물 $0.5 \mathrm{mg} / \mathrm{ml}$ 에서 $38 \%, 1$ $\mathrm{mg} / \mathrm{ml}$ 에서 $44 \%$ 의 저해활성이 나타났다. Positive control로 elastase 저해 활성 효과가 알려진 VitC는 $1 \mathrm{mg} / \mathrm{ml}$ 의 농도에서 $36 \%$ 의 저해활성이 나타났고 elastase 활성저해제인 oleanolic acid는 농도 $0.5 \mathrm{mg} / \mathrm{ml}$ 에서 elastase를 $32 \%$ 정도 저해하는 것으로 알려져 있으므로 주름 예방 효능에 있어서 감태 열수 추출물의 우수한 기능성이 예상 된다. 